\title{
Performance Factors of the Photovoltaic System: A Review
}

\author{
Noor Syahirah Mohd Hussin ${ }^{1}$, Nasrul Amri Mohd Amin ${ }^{1,}$ *, Muhammad Juhairi Aziz Safar ${ }^{1}$, Rina \\ Syazwani Zulkafli ${ }^{1}$, Mohd Shukry Abdul Majid ${ }^{1}$, Mohd Afendi Rojan $^{1}$ and Izzuddin Zaman ${ }^{2}$ \\ ${ }^{1}$ School of Mechatronic Engineering, Universiti Malaysia Perlis, Pauh Putra Campus, 02600 Arau, \\ Perlis, Malaysia. \\ ${ }^{2}$ Faculty of Mechanical and Manufacturing Engineering, Universiti Tun Hussein Onn Malaysia, Parit \\ Raja, 86400 Batu Pahat, Johor, Malaysia.
}

\begin{abstract}
Photovoltaic (PV) technology is one of the clean sustainable energy technology which sourced from the sun. However, there are many issues that can potentially degrade the system. This paper extensively discusses on the hybrid system power generation for the photovoltaic (PV) system. In addition, this paper also reviews the factor that affecting the photovoltaic system performance including the types of PV cell, the effect of ambient condition, system components, and the power quality characteristics. The performance of the monocrystalline type greater than the polycrystalline type around 5-7\%. The usage of an inverter gives an impact with $8-20 \%$ of total energy losses. Finally, this paper summarises the future research work needed to overcome the drawback of the available photovoltaic systems.
\end{abstract}

\section{Introduction}

Environmental issues such as climate changes and depletion of fossil fuel lead to the use of renewable energy [1]. Renewable energy is one of the best solutions for the growing energy demand challenge because of its unlimited, abundant and environmentally friendly sources [2]. The solar technology is capable of covering the world's electricity demands. Energy experts expected that in the year 2050 , over $50 \%$ of electrical energy could be produced by renewable energy sources. [3].

The average solar radiation around $400-600 \mathrm{MJ} / \mathrm{m}^{2}$ encourages the solar power installation in Malaysia. However, there are limitations due to the solar electricity tariff rate and the high installation cost [4]. The generated energy also leads to the greenhouse gasses emission. Malaysia has promised to cut about $40 \%$ of carbon emissions by the year 2020 [5]. In global, the energy demand is predicted to increase by 35\% between 2010 and 2040. Meanwhile, about 5.3\% increases of power generation in Malaysia is predicted for the time gap between 2005 to 2030 [5].

Recently, the hybrid renewable energy systems (HRES) become one of the alternative energy especially for the rural area. This is due to the unavailability of the utility grid power. In addition, HRES is a relatively cost-effective solution since the national utility grid is expensive. Thus, it is suitable for power applications in remote areas. Integrating distributed generating systems in mini-grid increases the reliability and quality of power [6].

\footnotetext{
*Corresponding author: nasrulamri.mohdamin@unimap.edu.my
} 
An extensive literature review has been carried out on the hybrid system and the factors that contribute to the PV performance efficiency. The limitations in the PV system also have been discussed in this study.

\section{Hybrid PV systems}

Hybrid system is a combination of energy system including renewable energy for an optimal output configuration [7]. The configuration can be a combination of a conventional energy with renewable energy systems or the combination of more than one renewable energy systems such as PV/Grid, PV/ Battery, PV/Wind and others. The presence of sunlight energy leads to the use of the hybrid power generation.

Hybrid PV systems can be divided into two types which are the grid-connected and stand-alone configuration as shown in Figure 1. The stand-alone hybrid system only depends on the alternative sources. An energy storage is required as a backup system during the shortage of solar radiation. The stand-alone system is more suitable for remote location due to the inaccessibility of the utility grid. In addition, the stand-alone type gets more attention as this system offers a low installation cost for applications in remote location [8].

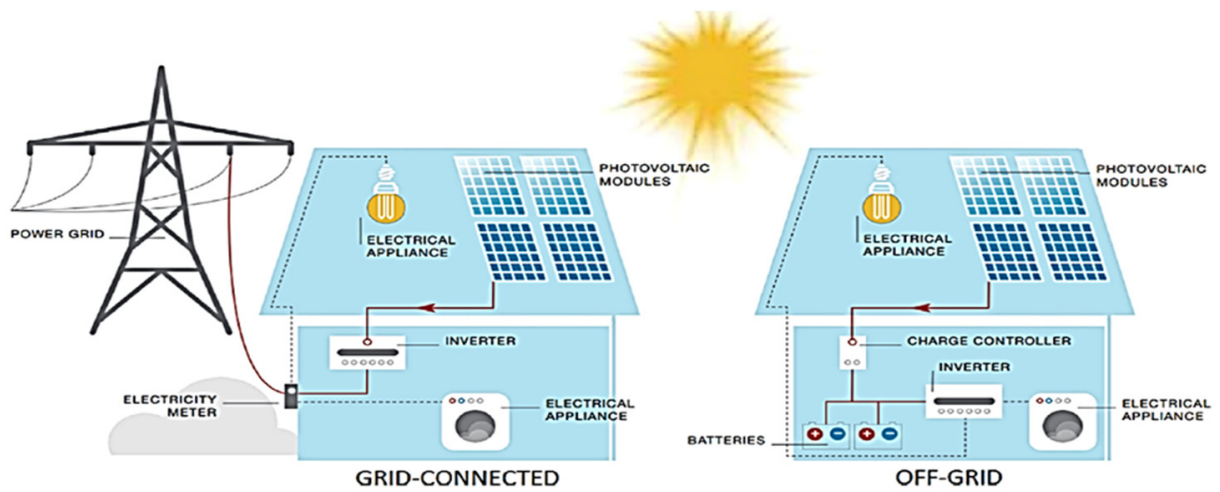

Fig. 1. Grid-connected and stand-alone/off-grid PV system configurations [35].

Grid-connected system is a combination of the utility grid and an alternative source systems. The system depends solely on the PV panel during daytime. During night time or when the solar radiation is low, the utility grid is used to supply the load demands. The large scale system can be implemented in the grid-connected system as it will increase the economic feasibility of the system. The grid-connected PV system is also capable of reaching a high efficiency due to the unlimited storage capacity. However, an appropriate configuration is needed to optimize the performance of the system [8].

\section{Factors affecting photovoltaic (PV) performance efficiency}

\subsection{Type of PV cell}

The type of PV cell also affecting the performance of the PV system. Recently, there are many type of PV cell have been commercialized in market. Table 1 shows the summary of the PV cell type. However, each type of them has their own strength. Nonetheless, customers still needs to deal with their limitation. For example, the polycrystalline modules experienced higher backside temperature compared to the monocrystalline modules when exposed to the same conditions [9]. In addition, the performance of the monocrystalline and 
power yield capacity of monocrystalline solar generation plant around 5\%-7\% greater than polycrystalline under the same condition [34].

The polycrystalline module in water pumping system also have been evaluated by the authors [10]. The result shows the power generated from the monocrystalline and polycrystalline module can pumps $3536.45 \mathrm{~L}$ and $4182.55 \mathrm{~L}$ of water, respectively. In addition, the efficiency of both modules was $9.40 \%$ and $6.57 \%$.

Table 1. Summary of the PV cell performance [36].

\begin{tabular}{|c|c|c|c|c|c|}
\hline \multirow[t]{2}{*}{ CELL TYPE } & \multicolumn{2}{|c|}{ CRYSTALLINE SILICON } & \multicolumn{3}{|l|}{ THIN FILM } \\
\hline & Monocrystalline & Polycrystalline & $\begin{array}{l}\text { Cadmium } \\
\text { Telluride }\end{array}$ & CIGS & $\begin{array}{l}\text { Amorphous } \\
\text { Silicon }\end{array}$ \\
\hline EFFICIENCY & $14-17.5 \%$ & $13-15 \%$ & $9-11 \%$ & $10-12 \%$ & $5-7 \%$ \\
\hline $\begin{array}{c}\text { HIGH TEMP. } \\
\text { PERFORMANCE }\end{array}$ & Drop 10-15\% & Drop $20 \%$ & $0 \%$ drop & $0 \%$ drop & $0 \%$ drop \\
\hline $\begin{array}{l}\text { OPTIMAL } \\
\text { TEMP. }\end{array}$ & $\begin{array}{l}\text { Perform well in } \\
\text { cool weather, } \\
\text { but poorly in } \\
\text { extreme heat }\end{array}$ & $\begin{array}{l}\text { Perform well in } \\
\text { cool weather, } \\
\text { but poorly in } \\
\text { extreme heat }\end{array}$ & $\begin{array}{c}\text { Perform } \\
\text { well in hot } \\
\text { weather, } \\
\text { but even } \\
\text { extreme } \\
\text { heat }\end{array}$ & $\begin{array}{l}\text { Perform } \\
\text { well in hot } \\
\text { weather, } \\
\text { but even } \\
\text { extreme } \\
\text { heat }\end{array}$ & $\begin{array}{l}\text { Perform well } \\
\text { in hot } \\
\text { weather, but } \\
\text { even } \\
\text { extreme heat }\end{array}$ \\
\hline COST & $\begin{array}{l}\text { Most expensive } \\
\text { crystalline } \\
\text { silicon }\end{array}$ & $\begin{array}{l}\text { Cheapest } \\
\text { crystalline } \\
\text { silicon }\end{array}$ & $\begin{array}{l}\text { Cheaper } \\
\text { than } \\
\text { crystalline } \\
\text { silicon. } \\
\text { Most cost- } \\
\text { effective } \\
\text { thin film }\end{array}$ & $\begin{array}{l}\text { Cheaper } \\
\text { than } \\
\text { crystalline } \\
\text { silicon }\end{array}$ & $\begin{array}{l}\text { Cheaper } \\
\text { than } \\
\text { crystalline } \\
\text { silicon }\end{array}$ \\
\hline $\begin{array}{l}\text { ADDITIONAL } \\
\text { DETAILS }\end{array}$ & $\begin{array}{l}\text { Oldest solar cell } \\
\text { technology and } \\
\text { most widely } \\
\text { used }\end{array}$ & $\begin{array}{l}\text { Economical } \\
\text { choice due to } \\
\text { its cost to } \\
\text { performance } \\
\text { ratio }\end{array}$ & $\begin{array}{l}\text { Cadmium } \\
\text { is toxic, } \\
\text { though } \\
\text { very small } \\
\text { amounts } \\
\text { used }\end{array}$ & $\begin{array}{l}\text { Come } \\
\text { CIGS } \\
\text { panels } \\
\text { have } \\
\text { posted } \\
\text { impressiv } \\
\text { e } 20 \% \\
\text { efficiency } \\
\text { figures }\end{array}$ & $\begin{array}{l}\text { Requires a } \\
\text { lot of roof } \\
\text { space and } \\
\text { can take } \\
\text { longer to } \\
\text { install than } \\
\text { other cell } \\
\text { technologies }\end{array}$ \\
\hline
\end{tabular}

\subsection{Effect of temperature, solar irradiance, and dust}

The performance of the PV output depends on the ambient temperature. Variations in solar radiation and ambient temperature influence the performance parameters [11]. The manufacturer operating data of the PV panel is limited, for instance the open circuit voltage $\left(V_{o c}\right)$, the short circuit current $\left(I_{s c}\right)$, the maximum power current $\left(I_{m p}\right)$, the maximum power voltage $\left(V_{m p}\right)$, the temperature coefficients at open circuit voltage and short circuit and the nominal operating cell temperature (NOCT). The data available at the standard rating condition (SRC) where the cell temperature is $25^{\circ} \mathrm{C}$ and the solar irradiance is $1000 \mathrm{~W} / \mathrm{m}^{2}$. This condition produced high power, nonetheless are rarely encountered in actual situation [12]. The equation below express the maximum PV power generated $P_{p v}$ [13] : 


$$
P_{p v}\left(T_{a}, G_{t o t}\right)=\eta_{p v}\left(T_{a}, G_{t o t}\right) S_{p v} G_{t o t}
$$

where:

$T_{a}=$ The ambient temperature

$G_{\text {tot }}=$ The total solar radiation

$\eta_{p v}=$ Efficiency of PV panel

$S_{p v}=$ Surface of PV panel

The solar panel efficiency can be prescribe from the cell temperature $T_{c}$ :

$$
\eta_{p v}\left(T_{c}, G_{\text {tot }}\right)=\eta_{\text {manuf }}\left(1-\beta_{p v}\left(T_{c}-T_{r}\right)\right)
$$

where:

$\eta_{\text {manuf }}=$ The manufacturer nominal efficiency

$\beta_{p v}=$ The temperature coefficient

$T_{r}=$ Reference temperature

In addition, the temperature cell is calculated from the solar radiation $G_{\text {tot }}$ and the ambient temperature $T_{a}$ as in Equation 3.

$$
T_{c}=T_{a}+\left(T_{N O C T}-T_{a, N O C T}\right) \frac{G_{t o t}}{G_{N O C T}}
$$

where $T_{N O C T}$ is the nominal temperature, $T_{a, N O C T}$ is the ambient temperature and $G_{N O C T}$ is a solar radiation under the Nominal Operating Cell Temperature (NOCT) conditions.

The other authors, [14] have investigated the effect of climate change on the solar PV power system in Australia using morphing method. The outcome of this study shows that the climate change causes the weather fluctuation which affects the PV power generation.

Furthermore, the PV module energy conversion efficiency generally is a non-linear function of the irradiance level and module temperature, normally declining for low irradiances and also for high temperatures [15]. The current and voltage that produced by the PV module are affected by solar irradiation level. The results show that the open circuit voltage and short circuit current directly proportional to the solar irradiance. The open circuit voltage and short circuit current decline with the reduction of the solar irradiance [16].

In addition, presence of dust also disturbs the PV efficiency. Basically, the dust was found at the surface of PV module. The experimental result done by [17] shows that the PV module efficiency will reduce from $7.2 \%$ to $5.6 \%$ during the dry period. The other authors, [9] have evaluated the power output of PV module based on the dust accumulation effect. The outcome of the studies shows that $50 \%$ of output power will be reduced if the PV panel is covered with the dust about six months. However, the presence of solar tracker increases the efficiency of PV output power and the dust accumulation effect able to be reduced by $50 \%$ at a peak time. The comparison of PV performance under clean and dusty conditions have been evaluated by [18]. The result shows that the maximum power loss for polycrystalline and monocrystalline module is about 18 to $78 \%$ respectively while maximum current loss is from $23 \%$ to $80 \%$ for both types.

\subsection{Effect of system components}

There are number of components in a solar photovoltaic hybrid system such as inverter, solar charger controller and energy storage. These components contribute to the solar 
output power. The selection of the system components is important in the preliminary design stage.

\subsubsection{Inverter}

The inverter is a component that converts the DC output power into AC power. The inverter is implemented in the grid-connected PV system to power up an AC load. However, the inverter sizing's strategies are often does not taken into account during the design stages. The inverter is sized with the nominal output power about $30 \%$ lower than the PV array nominal power. Initially, the efficiency is around $95-97 \%$ at the partial load but it will reduce gradually at full load. Undersized inverter operates at full load and depends on the solar irradiance. In addition, the undersized inverter can cause energy losses when reached at the operating temperature [19].

Moreover, the quality of equipment also gives an impact with 8-20\% of total energy losses of single-phase inverter[20]. The failure of inverter also occurs due to the lack of experience in the first production stage, grid disturbance, reclosing and other interconnecting problems [21]. Besides, the other researchers [22] have explored the impact of inverter configuration on the PV reliability. The result shows that the PV system performance decreases because of inverter failures such as inverter configuration, reliability characteristics of the inverter and the repair time.

\subsubsection{Charge controller}

The other important components in PV system is battery charge controller which is related to the batteries lifetime [23]. The authors [24] demonstrates the consequences of an on/off charge controller on PV system in terms of battery state-of-charge and the unused portion of the available PV array energy. The outcomes of the study showed that the battery SOC and PV energy is reduced by charge controlled about $10-15 \%$.

\subsubsection{Energy storage system}

The fluctuation of the solar output power contributes to the usage of the storage system. The minimum size of storage is needed to generate the PV integrated system without interruption [25], [26]. A variety of storage technologies is available, which is capable of smoothing out the unpredictable fluctuating output power [27]. There are two considerations for characterizing the application of an energy storage technology: 1) the amount of energy that can be stored in the device and 2) the energy rate that can be transferred into or out of the storage device. These factors depend mainly on the characteristic of the storage device itself [28].

Currently, there are many types of energy storage that have been commercialized including battery, flow battery, super capacitor and hydrogen storage. All of the energy storage holds different characteristics, applications and deployment status [29]. However, the state-of-charge (SOC) of the battery is important factors for the battery. The previous technology only limits the voltage in order to protect the battery from overcharge and deep discharge. This is because the excessively high or too low SOC can causes permanent battery damage [26]. Some of the issues related to the battery such as the deep discharge reduces the battery life cycle [30]. In additions, the lifetime of the battery depends on the operating condition like the depth of discharge cycles, the current, the cell voltage, the low state of charge duration and temperature [31]. 


\subsection{Effect of power quality requirement for the grid-connected PV system}

Another aspect that affects the performance of the PV system is power quality. The power systems are projected to run at a sinusoidal voltage of a given voltage and frequency. The power quality problems including any change of voltage, frequency and waveform in the system. Moreover, the variation of solar radiation will be resulting in the operating voltage and current fluctuations. However, only the voltage can be control in the power supply [32]. The other technical issues such as islanding detection, harmonic distortion requirements, and electromagnetic interference also reduce the photovoltaic system efficiency [21].

\subsection{Discussion}

There are numerous aspects need to be considered in order to achieve a better performance of photovoltaic systems. All the important aspects are discussed here.

The first factor is type of the PV cell. PV cells have many advantages corresponding to their types and materials. Nonetheless, PV cells also have some disadvantages. For example, the monocrystalline cell has high efficiency than the polycrystalline cell. However, the monocrystalline cell needs to undergo complex production process and more expensive compared to polycrystalline [33]. In addition, multi-junction PV cell can be implemented in order to achieve high-efficiency performance up to $40 \%$. The other method to improve the PV cell performance is concentrating the sunlight on PV cell using reflective materials [34], [35].

Moreover, the installation site is the important key of the overall performance of the PV system. The selection of the location can vary the parameter value of the temperature, irradiance, and dust effect. The increasing of solar irradiation influences the increasing of open voltage circuit while the increasing of cell temperature leads to the increasing of short circuit current. Hence, the cell efficiency will drop when the temperature of the cell is increased. The implementation of cooling material is the best solution to reduce the cell temperature. The dust accumulation lowers the light absorption and reduces the PV array efficiency. The dust issues can be minimized by installing the maximum power point tracking system.

In addition, the system component needs to be considered during the design stage. The component such as an inverter, charge controller, and storage system should be designed based on the size of the system. The component should not be oversized and compatible with the PV system. The charging and discharging of the battery affects the PV performances. Besides, not all type of inverters is suitable for the PV systems. The output power of the PV system is ineffectively generated to the load if the inverter has low efficiency. To overcome this issue, the inverter should be well-designed and the suitable inverter configuration should be chosen.

Lastly, the effect of power quality requirement also need to consider. The system will meets severe problem and losses when the power supply has low power quality. The major issue of power quality is harmonic distortion. However, this problem can be improved using Unified Power Quality Controller (UPQC) by considering the Advance Generalized Theory of Instantaneous Power (A-GTIP) algorithm [36].

In addition, the system component needs to be considered during the design stage. The component such as an inverter, charge controller, and storage system should be designed based on the size of the system. The component should not be oversized and compatible with the PV system. The charging and discharging of the battery affects the PV performances. Besides, not all type of inverters is suitable for the PV systems. The output power of the PV system is ineffectively generated to the load if the inverter has low 
efficiency. To overcome this issue, the inverter should be well-designed and the suitable inverter configuration should be chosen.

Lastly, the effect of power quality requirement also need to consider. The system will meets severe problem and losses when the power supply has low power quality. The major issue of power quality is harmonic distortion. However, this problem can be improved using Unified Power Quality Controller (UPQC) by considering the Advance Generalized Theory of Instantaneous Power (A-GTIP) algorithm [36].

\section{Conclusion}

A comprehensive literature review has been carried out on the effect of the PV systems performance. The overall performance is affected by the type of PV cell, ambient condition, system component and the power quality of the system. In addition, the available manufacturer operating data of the PV panel is limited. Hence, the future research involving a mathematical modeling analysis is proposed in order to study the overall performance of the system. An experimental work is needed for validation purposes.

The authors would like to thank the Ministry of Higher Education of Malaysia and Universiti Malaysia Perlis for providing financial support under the research grant no. FRGS (9003-00564).

\section{References}

1. T. Muneer, M. Asif, and J. Kubie, Energy Convers. Manag., 44, 35-52, (2003).

2. M. Asif and T. Muneer, Renew. Sustain. Energy Rev., 11, 1388-1413, (2007).

3. M. Z. A. Ab Kadir, Y. Rafeeu, and N. M. Adam, Renew. Sustain. Energy Rev., 14, 3023-3031, (2010).

4. S. Mekhilef, R. Saidur, and M. Kamalisarvestani, Renew. Sustain. Energy Rev., 16, 2920-2925, (2012).

5 F. M. Hossain, M. Hasanuzzaman, N. A. Rahim, and H. W. Ping, Clean Technol. Environ. Policy, 17, 859-871, (2015).

6. B. Bhandari, K. T. Lee, C. S. Lee, C. K. Song, R. K. Maskey, and S. H. Ahn, Appl. Energy, vol. 133, 236-242, (2014).

7. Y. S. Mohammed, M. W. Mustafa, and N. Bashir, Renew. Sustain. Energy Rev., 35, 527-539, (2014).

8. D. P. Kaundinya, P. Balachandra, and N. H. Ravindranath, Renew. Sustain. Energy Rev., 13, 2041-2050, (2009).

9. M. J. Adinoyi and S. A. M. Said, Renew. Energy, 60, 633-636, (2013).

10. C. E. C. Nogueira, M. L. Vidotto, R. K. Niedzialkoski, S. N. M. De Souza, L. I. Chaves, T. Edwiges, D. B. Dos Santos, and I. Werncke, Renew. Sustain. Energy Rev., 29, 151-157, (2014).

11. B. Marion, J. Adelstein, K. Boyle, H. Hayden, B. Hammond, T. Fletcher, B. Canada, D. Narang, A. Kimber, L. Mitchell, G. Rich, and T. Townsend, Conference Record of the Thirty-first IEEE Photovoltaic Specialists Conference, 2005., 16011606, (2005)

12. W. De Soto, S. A. Klein, and W. A. Beckman, 80, 78-88, (2006).

13. A. Bouabdallah, J. C. Olivier, S. Bourguet, M. Machmoum, and E. Schaeffer, Renew. Energy, 80, 266-274, (2015).

14. G. Liu, X.-H. Tan, and M. Li, Energy Procedia, 61, 2588-2591, (2014).

15. T. Huld, R. Gottschalg, H. G. Beyer, and M. Topič, Sol. Energy, 84, 324-338, (2010).

16. M. A. Islam, A. Merabet, R. Beguenane, and H. Ibrahim, 2013 IEEE Electr. Power 
Energy Conf., 1-6, (2013).

17. J. D. Bastidas-Rodriguez, C. A. Ramos-Paja, and E. Franco-Mejía, Ingeniería, 17, 37-48, (2012).

18. A. Ndiaye, C. M. F. Kébé, P. A. Ndiaye, A. Charki, A. Kobi, and V. Sambou, Int. J. Phys. Sci., 8, 1166-1173, (2013).

19. B. Burger and R. Rüther, Sol. Energy, 80, 32-45, (2006).

20. A. Fernández-Infantes, J. Contreras, and J. L. Bernal-Agustín, Renew. Energy, 31, 2042-2062, (2006).

21. M. A. Eltawil and Z. Zhao, Renew. Sustain. Energy Rev., 14, 112-129, (2010).

22. A. Pregelj, M. Begovic, and A. Rohatgi, Conf. Rec. Twenty-Ninth IEEE Photovolt. Spec. Conf. 2002., 1388-1391, (2002).

23. J. L. Bernal-Agustín and R. Dufo-López, Renew. Sustain. Energy Rev., 13, 21112118, (2009).

24. L. Sanidad, R. Parsons, Y. Baghzouz, and R. Boehm, Collect. Tech. Pap. 35th Intersoc. Energy Convers. Eng. Conf. Exhib., 2, 1497-1501, (2000).

25. R. Khalilpour and A. Vassallo, Renew. Sustain. Energy Rev., 53, 194-208, (2016).

26. S. Piller, M. Perrin, and A. Jossen, J. Power Sources, 96, 113-120, (2001).

27. D. B. Nelson, M. H. Nehrir, and C. Wang, Renew. Energy, 31, 1641-1656, (2006).

28. P. F. Ribeiro, B. K. Johnson, M. L. Crow, A. Arsoy, and Y. Liu, Proc. IEEE, 89, (2001).

29. H. Chen, T. N. Cong, W. Yang, C. Tan, Y. Li, and Y. Ding, Prog. Nat. Sci., 19, 291-312, (2009).

30. C. J. Rydh and B. A. Sandén, Energy Convers. Manag., 46, 1957-1979, (2005).

31. J. Carroquino, R. Dufo-López, and J. L. Bernal-Agustín, Renew. Energy, 76, 566574, (2015).

32. A. Zahedi, Renew. Sustain. Energy Rev., 15, 866-870, (2011).

33. G. Makrides, B. Zinsser, G. E. Georghiou, M. Schubert, and J. H. Werner, Sol. Energy Mater. Sol. Cells, 93, 1095-1099, (2009).

34. J. C. C. Fan, M. B. Spitzer, and R. P. Gale, "High-Efficiency 111-V Solar Cells," 395-426, (1990).

35. M. N. B. Y. S. R. B. Srinivas, S.Balaji, "Review on Present and Adwance Materials for Solar Cells," 3, 166-169, (2015).

36. A. R. Reisi, M. H. Moradi, and H. Showkati, Sol. Energy, 88, 154-162, (2013). 